\title{
In vitro antioxidant capacities and phenolic contents of four Erica L. (Ericaceae) taxa native to Turkey
}

\author{
Ayşegül KÖROĞLU 1, Muhammed Mesud HÜRKUL ${ }^{1}$, Gülsen KENDİR ${ }^{2}{ }^{*}$, Nurgün KÜÇÜKBOYACI ${ }^{3}$ \\ 1 Ankara University, Faculty of Pharmacy, Department of Pharmaceutical Botany, 06100 Tandoğan, Ankara, Turkey. \\ 2 İstinye University, Faculty of Pharmacy, Department of Pharmaceutical Botany, 34010 Zeytinburnu, İstanbul- \\ Turkey. \\ 3 Gazi University, Faculty of Pharmacy, Department of Pharmacognosy, 06330 Etiler, Ankara, Turkey. \\ * Corresponding Author. E-mail: kendir08@gmail.com (G.K.); Tel. +90-505-848 99 78; ORCID No: 0000-0001-8879- \\ 3751
}

Received: 19 February 2018 / Revised: 03 June 2018 / Accepted: 05 June 2018

\begin{abstract}
Erica species (Ericaceae) are widely used due to their medicinal properties in Turkish folk medicine. In this study, the antioxidant capacities of the extracts with different polarities of the aerial parts of Erica arborea, E. manipuliflora, E. bocquetii and E. sicula subsp. libanotica native to Turkey were investigated. 1,1-diphenyl-2-picrylhydrazyl (DPPH•) radical scavenging and the thiobarbituric acid (TBA) test systems used for the determination of antioxidant capacities. Also, total phenol contents in the extracts were determined as spectrophotometric. All extracts exhibited strong scavenging activity against DPPH except the chloroform extracts. Ethyl acetate extracts of Erica species had the best scavenging activity against DPPH, as well as the highest DPPH scavenging activity was exhibited by E. manipuliflora and E. bocquetii with $\mathrm{IC}_{50}$ values of $0.002 \pm 0.001$ and $0.004 \pm 0.000 \mu \mathrm{g} / \mathrm{mL}$, respectively. In TBA test, the highest activity was observed in the ethyl acetate extract of E. manipuliflora $\left(\mathrm{IC}_{50}=0.001 \pm 0.000 \mu \mathrm{g} / \mathrm{mL}\right.$ ), followed by the water extract of this plant $(0.03 \pm 0.005 \mu \mathrm{g} / \mathrm{mL})$. The highest total phenolic content was found in the ethyl acetate extracts ranging from 875.5 to $701.7 \mathrm{mg} \mathrm{GAE} / \mathrm{g}$ extract. Our results showed that the ethyl acetate extracts of Erica taxa are rich in natural antioxidant substances.
\end{abstract}

KEYWORDS: Erica; Turkey; antioxidant capacity; total phenolic content.

\section{INTRODUCTION}

The family Ericaceae is represented by 100 genus and 3000 species and widely distributed in Himalayas, New Guinea and South Africa [1]. In Turkey, there are 12 genus and about 30 species in the family. The genus Erica L. (Ericaceae) is mostly found with more than 700 species in South Africa, West Europe and Mediterranean regions. This genus is represented by five taxa in flora of Turkey and one of them, E. bocquetii (Peşmen) P. F. Stevens, is an endemic species for Turkey. E. arborea L. and E. manipuliflora Salisb., are widely distributed in the coastal regions of Turkey. However, E. sicula Guss. subsp. libanotica (C. \& W. Barbey) P. F. Stevens is presented only in the South West of Anatolia [2] and E. spiculifolia Salisb. is a new species, which was separated from the genus Bruckenthalia Reichb [3] These species are named "funda", "püren" or "süpürge çalısı" in Turkey [4]. Regarding the International Union for the Conservation of Nature and Natural Resources (IUCN) Red Data Book, E. sicula subsp. libanotica and E. bocquetii are evaluated in "Vulnerable" (VU) status in Turkey [5].

Herba Ericae is a natural drug consisting of dried leaves and flowers of Erica species, especially $E$. arborea and E. manipuliflora. In Turkish folk medicine, this drug is widely used as diuretic, astringent and treatment for urinary infections [4,6]. On the other hand, 5\% infusion of E. arborea is taken after meals for slimming purposes [7]. Furthermore, a decoction of the aerial parts of E. arborea is used as diuretic in Italy [8] as well as E. multiflora is also used as diuretic and antiseptic agent in Morocco [9]. In addition, E. multiflora has been reported that it is used for wound treatment in Spain [10].

Erica species mainly contain flavonoids [11, 12], anthocyanins [13], phenylpropanoid glycosides [14], coumarins [15] and triterpenic compounds [16]. Genus Erica has been investigated for their biological acitivites such as antiulcer [17], anti-inflammatory, antinociceptive [18], antimicrobial [16, 19-22], antilithic

How to cite this article: Köroğlu A, Hürkul MM, Kendir G, Küçükboyacı N.. In vitro antioxidant capacities and phenolic contents of four Erica L. (Ericaceae) taxa native to Turkey. J Res Pharm. 2019; 23(1): 93-100. 
[23] and cytotoxic [21,24] activities. There are several reports on the antioxidant activity of Erica species [21, 22] except E. arborea [11, 12, 21, 25-28].

Free radicals are molecules which contain one or more unpaired electrons. These highly reactive molecules which tend to initiate chain reactions with other molecules are also known as oxidants or reactive oxygen particles [29]. It is widely accepted that virtually every state of any disease involves some degree of oxidative stress and free radicals which can be obviated by the administration of either exogenous and endogenous antioxidants or free radical scavengers [30]. Medicinal plants, vegetables and spices are known as the primary sources of naturally occurring antioxidants [31-33]. Antioxidants, used in typical diets, are derived from plant sources, containing various compounds with a wide variety of physical and chemical properties. The most important characteristic of an antioxidant is free radical scavenging or the ability to trap free radicals [33]. Phenolics, including phenols, phenolic acids, flavonoids, tannins and lignans are the main sources of natural antioxidants. Antioxidants due to phenolic groups, which are excellent nucleophiles and lipid peroxidation inhibitors, cease the reaction of oxidation by binding free radicals in several ways. In addition, phenolic compounds act as chelating agents of metal ions that induce oxidation [32]. Significant evidence suggests that foods containing antioxidants and especially antioxidant nutrients may have importance in preventing diseases [34].

Currently, 19 in vitro and 10 in vivo methods are used for antioxidant evaluation. DPPH scavenging activity method is the most commonly used for assessing antioxidant activity as in vitro, while lipid peroxidation assay has been found as the most commonly used method as in vivo [34].

This study was conducted to carry out a comparative study on four Erica species native to Turkey in five different solvent extracts to determine their antioxidant capacities as well as total phenolics and flavonoids. Antioxidant effect of the extracts was tested for their scavenging activity against DPPH and antilipid capacity using TBA test.

\section{RESULTS AND DISCUSSION}

This study was carried out to determine the total phenolics and total flavonoids as well as the in vitro antioxidant capacity of different extracts prepared from four Erica taxa used as natural medicines in Turkish folk medicine. Figure 1 shows an overview of the total phenolic contents of Erica taxa. Maximum total phenolic content was found in EtOAc (Ethyl acetate) extracts of E. arborea $(877.5 \pm 19,29 \mathrm{mg}$ gallic acid equivalent $(\mathrm{GAE}) / \mathrm{g})$, followed by E. bocquetii $(810 \pm 14,95 \mathrm{mg} \mathrm{GAE} / \mathrm{g})$, E. manipuliflora $(735.5 \pm 19,35 \mathrm{mg}$ $\mathrm{GAE} / \mathrm{g})$ and E. sicula subsp. libanotica $(701.7 \pm 10,2 \mathrm{mg} \mathrm{GAE} / \mathrm{g})(p<0.05)$. Furthermore, the plates were sprayed with $1 \%$ vanillin- $\mathrm{H}_{2} \mathrm{SO}_{4}$, antioxidant compounds were detected mainly the flavonoids. Kaempferol and luteolin together with water, EtOAc and $n-\mathrm{BuOH}$ extracts of Erica species have been showed yellow and orange fluorescence in UV light $(365 \mathrm{~nm})$ after spraying. The radical scavenging capacity of the extracts from four Erica species was evaluated by using qualitative and quantitative DPPH assays. The highest free radical scavenging effects in both systems were found in EtOAc extracts of E. bocquetii $\left(\mathrm{IC}_{50}=0.004 \pm 0.000 \mu \mathrm{g} / \mathrm{mL}\right.$ ) and E. manipuliflora $\left(\mathrm{IC}_{50}=0.002 \pm 0.001 \mu \mathrm{g} / \mathrm{mL}\right)(p<0.05)$. E. sicula subsp. libanotica also displayed the highest effect in quantitative DPPH assays $\left(\mathrm{IC}_{50}=0.002 \pm 0.000 \mu \mathrm{g} / \mathrm{mL}\right.$ ), similar to E. manipuliflora. Water extracts of Erica species usually showed higher effect than the propyl gallate used as standard $(p<0.05)$ in this test. The results of the qualitative DPPH test showed that EtOAc extracts of E. bocquetii and E. manipuliflora was appeared more prominent yellow zones on purple background than the others. The free radical scavenging capacities of Erica extracts were in the following order: EtOAc> water> $\mathrm{MeOH}$ (methanol) $>n-\mathrm{BuOH}(n-$ butanol) $>\mathrm{CHCl}_{3}$ (chloroform). The $\mathrm{IC}_{50}$ values for antioxidant capacity of all the plants are given in Figure 2 . All samples inhibited DPPH radicals in a concentration-dependent manner.

The inhibitory capacities of the extracts against lipid peroxidation on liposomes are shown in Table 1. In the TBA method, all the extracts of Erica species were shown to possess significant anti-lipid peroxidation capacity in in vitro system. The most active extracts were found to be EtOAc and water extracts of $E$. manipuliflora with $\mathrm{IC}_{50}=0.001 \pm 0.000 \mu \mathrm{g} / \mathrm{mL}$ and $0.03 \pm 0.005 \mu \mathrm{g} / \mathrm{mL}$, respectively. These extracts exhibit a higher activity than the propyl gallate used as standard $\left(\mathrm{IC}_{50}=0.14 \pm 0.01 \mu \mathrm{g} / \mathrm{mL}\right)$. 


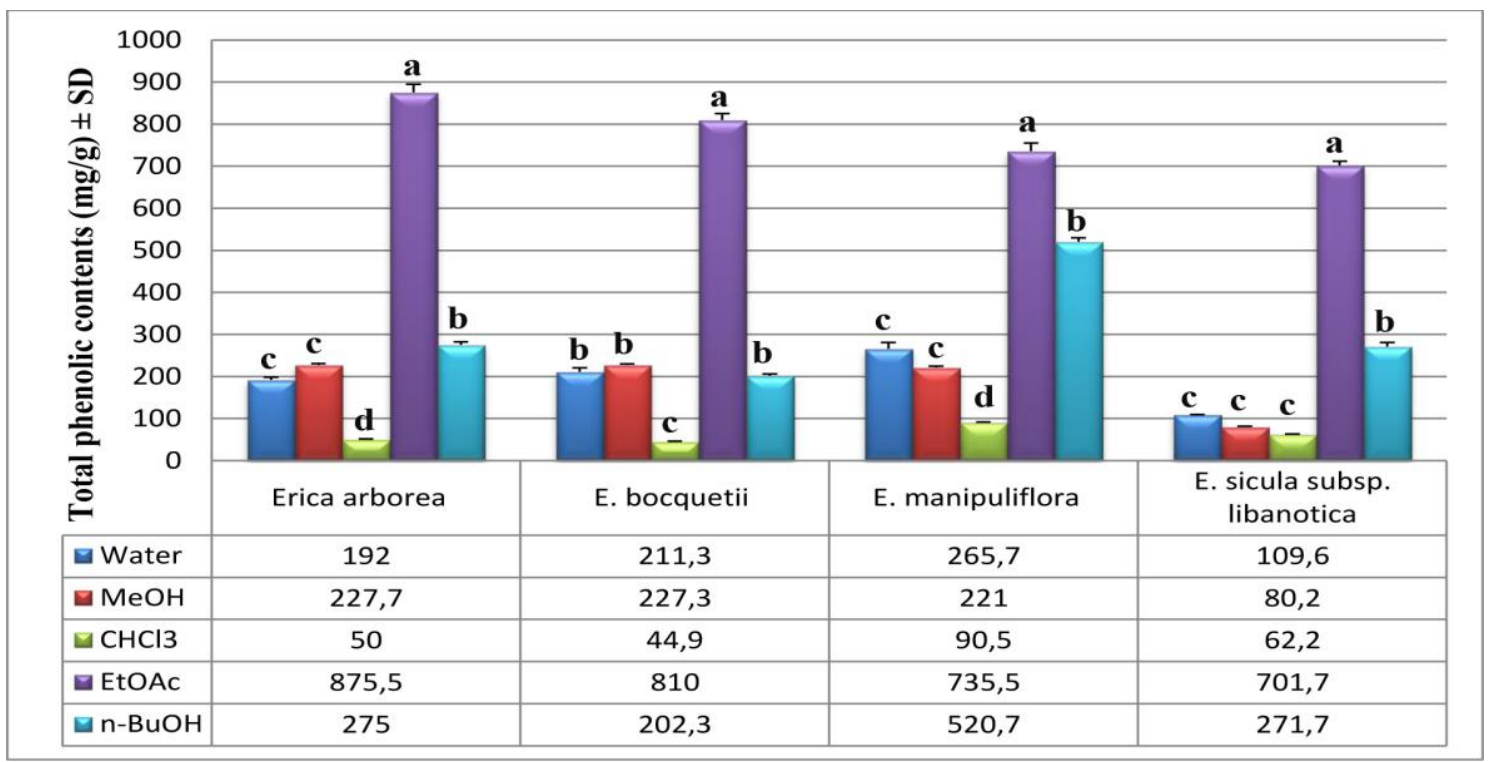

Figure 1. Total phenolic contents of the extracts of Erica taxa. Means with different letters in the same plant represent significantly difference at the level $(p<0.05) ; n=3$.

We usually observed higher values for total phenolic content and antioxidant activity than the literature findings. Turgay and Esen (2015) have been reported that the acidified methanol extract of $E$. manipuliflora showed moderate antioxidant capacity in DPPH scavenging capacity test $\left(\mathrm{IC}_{50}=255.9 \mathrm{mg} / \mathrm{mL}\right)$. Besides, they determined its amount of total phenolic as $260 \mathrm{mg}$ GAE/gr. In that study, the plant material has been purchased from local supermarkets, due to this reason it may not be a fresh plant [22]. In other previous study, the antioxidant activities of some polar extracts such as ethanol, methanol and water of $E$. bocquetii ( $2.36 \pm 0.01$ millimolar $(\mathrm{mM}), 2.65 \pm 0.00 \mathrm{mM}, 2.6 \pm 0.03 \mathrm{mM}$, respectively) were higher than those of Erica arborea $(1.63 \pm 0.07 \mathrm{mM}, 1.92 \pm 0.06 \mathrm{mM}, 1.92 \pm 0.12 \mathrm{mM})$ in TEAC assay were demonstrated [21]. In another previous study, the antioxidant capacities of methanol, ethyl acetate, butanol and water extracts of aerial parts of E. arborea were determined. The ethyl acetate extract was found to be richest in terms of phenolic $(315.52 \pm 3.81$ microgram $(\mu \mathrm{g})$ pyrocatechol equivalents $/ \mathrm{mg}$ extract) and flavonoid $(150.42 \pm 1.63 \mu \mathrm{g}$ quercetin equivalents/mg extract) contents which exhibited the highest antioxidant activity in especially DPPH assay $\left(\mathrm{IC}_{50}=5.98 \pm 0.09 \mathrm{mg} / \mathrm{mL}\right)$ [25]. In other study, the ethanolic extract of $E$. arborea exhibited notable antioxidant activity in FRAP (Ferric-reducing antioxidant power) $\left(3.55 \pm 0.11\right.$ millimol $\mathrm{Fe}^{2+} \mathrm{g}$ ), lipid peroxidation $(62.5 \mathrm{mg} / \mathrm{ml} ; 78.97 \%)$ and DPPH free radical scavenging activity $(13.40 \pm 0.67 \mu \mathrm{g} / \mathrm{mL})$ tests with the high total polyphenols and tannins values $(28.00 \pm 0.25$ and $21.86 \pm 0.09 \%$, respectively) [27]. Water extracts of different parts such as leaves, flowers and branches of E. arborea were investigated for their phenolic and flavonoid contents, and antioxidant activity using in vitro tests such as total antioxidant activity, FRAP, reducing power, DPPH and ABTS (2-2'-azino-bis (3-ethylbenzothiazoline-6-sulfonic acid). The leaves were found to be have the highest total phenolic (30.6 mg GAE/g) and flavonoid (4 mg quercetin equivalent/g) contents. In all tests, the leaves usually showed the highest antioxidant activity [28]. Furthermore, phenylethanoids $\left(\mathrm{RC}_{50}=11.11 \pm 10^{-2}\right.$ to $2.44 \pm 10^{-5} \mathrm{mg} / \mathrm{mL}$ ) and flavonoids $\left(\mathrm{RC}_{50}=15.6 \times 10^{-3}\right.$ to $17.2 \times 10^{-3}$ $\mathrm{mg} / \mathrm{mL}$ ) obtained from the methanol extract of E. arborea leaf exhibited significant antioxidant capacity in DPPH assay [11, 12]. The methanol extract of E. arborea leaf also displayed considerable antioxidant capacity in DPPH assay $\left(\mathrm{RC}_{50}=9.9 \pm 10^{-3} \mathrm{mg} / \mathrm{mL}\right)[12] \mathrm{s}$.

E. manipuliflora is widely used as herbal tea in folk medicine in Turkey [4]. However, regarding the results from the TBA, $\mathrm{CHCl}_{3}$ extracts of studied taxa have low antioxidant capacity compared with propyl gallate. These results are in agreement with the results of the free radical scavenging capacity. 


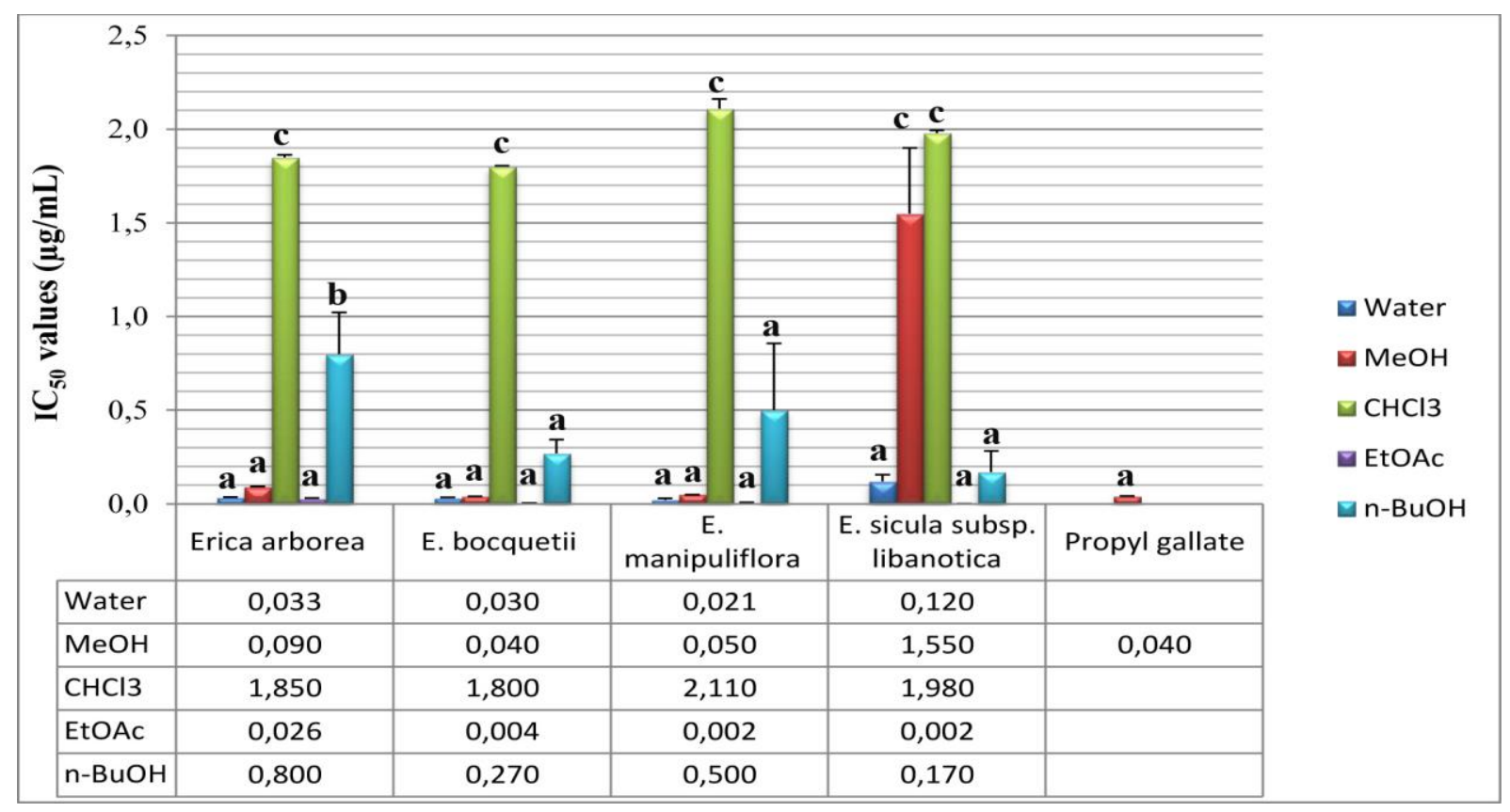

Figure 2. Free-radical scavenging activity by quantitative DPPH of the extracts of Erica taxa. Means with different letters in the same plant represent significantly difference at the level $(p<0.05) ; \mathrm{n}=3$.

Phenolic substances have been shown responsible for the antioxidant capacity of plants [31, 32, 35]. EtOAc extracts of Erica taxa were found to have significantly high content of total phenols. These results are in a good agreement with the literature [18, 20, 25]. Erica species contain flavonoids, anthocyanins, coumarins and terpenoid compounds $[10,13,15,16,25]$. As soon as the plates were sprayed with $1 \%$ vanillin- $\mathrm{H}_{2} \mathrm{SO}_{4}$, antioxidant compounds were detected mainly the flavonoids, especially in the EtOAc extracts, because of the observance of the characteristic yellow and orange bands in the fluorescence under UV light $(365 \mathrm{~nm})$ after the spraying process [36]. In our study, after the development procedure following the spraying process on TLC (thin layer chromatography), distinct yellow and orange zones were observed in the fluorescence under UV light. These results are in good accordance with the results of total phenolic compounds (Figure 1). Furthermore, the highest free radical scavenging capacity (Figure 2) and inhibition of lipid peroxidation (Table 1) were observed in EtOAc extracts. It is reported that there is a strong correlation between total phenolic contents, antiradical and anti-lipid peroxidative capacities of the compounds. Scavenging and inhibition of lipid peroxidation capacities of EtOAc extracts of Erica taxa may be attributed to their phenolic contents, especially flavonoids. The EtOAc extract of E. arborea has been found to have the richest phenolic and flavonoid content [(-)-epicatechin and quercitrin] and showed the highest antioxidant capacity [25]. The antioxidant capacity of phenolics is mostly related to their reduction properties, which allow them to act as hydrogen donors and singlet oxygen quenchers. In recent years the powerful antioxidant capacity of the flavonoids has been attracting much attention [37].

Table 1. Antioxidant activities of the Erica taxa in the TBA test.

\begin{tabular}{|c|c|c|c|c|c|}
\hline \multirow[b]{2}{*}{ Species } & \multicolumn{5}{|c|}{ IC $_{50}$ value $(\mu \mathrm{g} / \mathrm{mL}) \pm \mathrm{SEM}$} \\
\hline & Water extracts & $\mathrm{MeOH}$ extracts & $\mathrm{CHCl}_{3}$ extracts & EtOAc extracts & $\begin{array}{l}n-\mathrm{BuOH} \\
\text { extracts }\end{array}$ \\
\hline Erica arborea & $1.02 \pm 0.01$ & $2.65 \pm 0.15$ & $\geq 50 \pm 0.9$ & $0.22 \pm 0.04$ & $13.54 \pm 0.2$ \\
\hline E. bocquetii & $19.92 \pm 0.06$ & $4.05 \pm 0.01$ & $\geq 50 \pm 0.6$ & $2.65 \pm 0.02$ & $25.98 \pm 0.06$ \\
\hline E. manipuliflora & $0.03 \pm 0.005$ & $3.03 \pm 0.6$ & $\geq 50 \pm 1.8$ & $0.001 \pm 0.000$ & $2.77 \pm 0.06$ \\
\hline E. sicula subsp. libanotica & $10.15 \pm 0.01$ & $29.1 \pm 0.5$ & $\geq 50 \pm 1.8$ & $0.31 \pm 0.02$ & $15.04 \pm 0.01$ \\
\hline Propyl gallate & $0.14 \pm 0.01$ & & & & \\
\hline
\end{tabular}

SEM: Standard error mean; TBA: Thiobarbituric acid; $\mathrm{IC}_{50}$ : Inhibitory concentration. 


\section{CONCLUSION}

The data obtained are to verify the ethnopharmacological use of these Turkish Erica taxa. E. arborea and E. manipuliflora are used as infusion or decoction form in folk medicine in Turkey. The results obtained in this study are expected to establish a firm basis for the future studies in this area. It was observed that these plants have great potential as the natural antioxidant compounds. Further bioassay-guided fractionation procedures are necessary to characterize and isolate the active constituents for E. manipuliflora. In vivo and clinical studies could be conducted on the active constituents of this species and, based on the results obtained, these active constituents could be a source of pharmaceutical preparations. This work is the first study for evaluating of antioxidant capacity of E. sicula subsp. libanotica growing in Turkey.

\section{MATERIALS AND METHODS}

\subsection{Plant materials}

Plant materials were collected from different regions of Turkey in their natural habitats. Voucher samples were kept in the Ankara University Faculty of Pharmacy Herbarium (AEF), Turkey. Localities, collection periods and herbarium numbers of the species studied are as follows: E. arborea: A3 Bolu: Akçakoca, ca. 300 m, 19.05.2006, A. \& U. Güvenç, M. Coşkun (AEF 23874); E. manipuliflora: C6 Hatay: Dörtyol, 1100 m, 07.09.2003, G. Kendir (AEF 23013); E. sicula subsp. libanotica: C3 Antalya: Kemer Beldibi, 42 m, 10.05.2003, R. S. Göktürk, G. Kendir (AEF 23009); E. bocquetii: C2 Antalya: Çı̆̆lıkara, 1750 m, 19.07.2003, A. \& U. Güvenç, R. S. Göktürk (AEF 23016).

\subsection{Chemicals}

Methanol (Merck 1.06008-extra pure), Chloroform (Merck 1.02431-extra pure), Ethyl acetate (Merck 1.00864-extra pure), $n$-Butanol (Merck 16904588), Folin-Ciocalteu reagent (Molychem 31740), $\mathrm{Na}_{2} \mathrm{CO}_{3}$ (SigmaAldrich 13418-1KG-R), Gallic acid (Merck), DPPH• reagent (Aldrich D211400), Phosphate buffer (Biomatik A3602), Ferric cloride (Sigma F1513), Ascorbic acid (Aldrich 25,556-4), Thiobarbituric acid (Sigma-Aldrich T5500), Butylated hydroxytoluene(Sigma-Aldrich B1378), Brain extract (Sigma-Aldrich B3635), Proply gallate (Aldrich P5,330-6), kaempferol (Sigma K0133), luteolin (Sigma L9283), TLC plates (Merck).

\subsection{Preparation of extracts}

After drying the aerial parts (including of stem, leaves and flowers) of plant materials under shade, the materials were powdered to a fine grade in a mechanical grinder.

\subsubsection{Water extracts}

Twenty gram of aerial parts of plants were extracted by refluxing with distilled water $(100 \mathrm{~mL})$ for 30 min. The extracts were filtered when hot and then the resultant extracts were lyophilized.

\subsubsection{Methanol $(\mathrm{MeOH})$ extracts}

Twenty gram of aerial parts of the plants were macerated with methanol $(\mathrm{MeOH} ; 3 \times 250 \mathrm{~mL})$ for $8 \mathrm{~h}$ at $60{ }^{\circ} \mathrm{C}$. The methanol extracts were filtered and then evaporated in vacuo at $40^{\circ} \mathrm{C}$.

\subsubsection{Solvent fractionation}

Forty gram powdered herbs of the species studied were macerated with $\mathrm{MeOH}(3 \times 250 \mathrm{~mL})$ for $8 \mathrm{~h}$ at $60{ }^{\circ} \mathrm{C}$. Following filtration, the combined methanol extract was evaporated to dryness in vacuo at $40{ }^{\circ} \mathrm{C}$. The crude methanol extract was dissolved in $50 \mathrm{~mL}$ of $\mathrm{H}_{2} \mathrm{O}: \mathrm{MeOH}(9: 1, \mathrm{v} / \mathrm{v})$ and then this solution was extracted successsively with chloroform $\left(\mathrm{CHCl}_{3} ; 3 \times 150 \mathrm{~mL}\right)$, ethyl acetate (EtOAc; $\left.3 \times 150 \mathrm{~mL}\right)$ and $n$-butanol saturated with distilled water $(n-\mathrm{BuOH} ; 3 \times 150 \mathrm{~mL})$. Each extract was evaporated to dryness under reduced pressure.

\subsection{Determination of total phenolic content}

Total phenolic content of the extracts was determined according to the Folin-Ciocalteau method, referring to the calibration curve of gallic acid which a phenolic compound used as a standard [38]. The extracts in the concentration of $2 \mathrm{mg} / \mathrm{mL}$ was used in the analysis. According to this method, $50 \mu \mathrm{L}$ samples were mixed with $250 \mu \mathrm{L}$ of Folin-Ciocalteu's reagent and $500 \mu \mathrm{L}$ of $20 \%(w / v)$ aqueous $\mathrm{Na}_{2} \mathrm{CO}_{3}$. The volume was made up to $5 \mathrm{~mL}$ with distilled water. After incubation of the samples at room temperature for $30 \mathrm{~min}$, 
the absorbances of the samples were read at $765 \mathrm{~nm}$ on a Shimadzu UV-1800 Spectrophotometer. Total phenolic content was measured as gallic acid equivalent (GAE) and expressed in mg GAE/g extract (dw) \pm standard error mean (SEM). All experiments were performed in triplicate.

\subsection{Qualitative determination of flavonoid}

5 microliter of 1 milligram/milliliter Erica extracts prepared from the different polarity solvents were applied to silica gel TLC plates (Merck 5554, Darmstadt, Germany) by the use of Wiretrol II micropipettes. The TLC plate was developed with the mixture of $\mathrm{CHCl}_{3}: \mathrm{MeOH}$ :distilled water (80:20:2) and then sprayed with $1 \%$ vanillin- $\mathrm{H}_{2} \mathrm{SO}_{4}$ solution. The plate was heated for $5 \mathrm{~min}$ at $110{ }^{\circ} \mathrm{C}$ before being examined under UV light $(365 \mathrm{~nm})$. Flavonoids appeared as yellow and orange zones [31, 36]. Kaempferol (Sigma K0133) and luteolin (Sigma L9283) were used as reference substances.

\subsection{Antiradical capacity}

The free radical scavenging activity of the extracts has been investigated by using qualitative and quantitative $\mathrm{DPPH} \cdot$ tests.

\subsubsection{Qualitative DPPH•}

$\mathrm{DPPH} \cdot$ assay was used as a rapid TLC screening method for evaluation of the free radical scavenging capacity of $\mathrm{MeOH}, \mathrm{CHCl}_{3}, \mathrm{EtOAc}, n-\mathrm{BuOH}$ and water extracts of four Erica species. When TLC plate is sprayed with $\mathrm{DPPH}^{\cdot}$ solution, the antioxidant compounds in samples are observed as yellow zones on a purple background. $2 \mu \mathrm{g} / \mathrm{mL}$ of all extracts were applied to the TLC plate. The TLC plate was sprayed with $0.2 \%$ DPPH (Aldrich D 211400) solution in $\mathrm{MeOH}$ and left for $30 \mathrm{~min}$ at $20^{\circ} \mathrm{C}$ and then it was examined [31]. Propyl gallate was used as a positive control.

\subsubsection{Quantitative DPPH•}

DPPH radical scavenging capacity was evaluated by the method described by Brand-Williams et al. (1995) [39]. The extracts were dissolved in methanol, then $0.1 \mathrm{~mL}$ of each extract at different concentrations $(0.016-1 \mathrm{mg} / \mathrm{mL})$ was mixed with $2.9 \mathrm{~mL}$ of freshly prepared $10^{-4} \mathrm{M}$ DPPH solution and left in a water bath for $30 \mathrm{~min}$ at $30{ }^{\circ} \mathrm{C}$. Following incubation, the decrease in absorbance at $517 \mathrm{~nm}$ was measured using a Shimadzu UV-1800 Spectrophotometer. Propyl gallate was used as a positive control. The inhibition of DPPH radicals was calculated as follows:

\section{$\%$ DPPH radical scavenging capacity $=[(\mathrm{Ao}-\mathrm{As}) / \mathrm{Ao}] \times 100$}

$A o=$ the absorbance of the control and $A s=$ the absorbance of the sample or reference.

The $\mathrm{IC}_{50}$ value of the extracts was calculated by linear regression analysis. All analyses were performed triplicate and the results were expressed as mean values \pm standard error mean (SEM).

\subsection{Anti-lipid peroxidation capacity}

The lipid peroxidation capacity was measured by the use of thiobarbituric acid (TBA) test described by Conforti et al. (2002) [31,35]. Different concentrations of the extracts $(0.016-1 \mathrm{mg} / \mathrm{mL})$ and propyl gallate $(0.000064-1 \mathrm{mg} / \mathrm{mL})$ as reference were tested for their lipid peroxidation capacity against liposomes prepared from bovine brain. The absorbance was measured at $532 \mathrm{~nm}$ by a Shimadzu UV-1800 Spectrophotometer. The inhibition of lipid peroxidation was calculated as follows:

$$
\% \text { Inhibition }=100 \times \frac{\left(A_{o}-B\right)-(A s-B-E A)}{\left(A_{o}-B\right)}
$$

$\mathrm{A}_{0}=$ the absorbance of control reaction, $\mathrm{B}=$ the absorbance of the blank mixture (liposomes only), As= absorbance of the sample, EA= the absorbance due to the extract alone.

The $\mathrm{IC}_{50}$ value of the extracts was calculated by linear regression analysis. Four replicate experiments were performed for each extract and the results were given as mean values \pm standard error mean (SEM). 


\subsection{Statistical analysis}

Statistical analysis were conducted by using SPSS Statistics 20 software (IBM Corporation, Armonk, NY) and one-way analysis of variance (one-way ANOVA, Tukey's test). A statistical significance of $p<0.05$ was considered to be significant.

Acknowledgments: The financial support of the research fund of Ankara University (Project number 20030803044 ) is gratefully acknowledged.

Authorship statement: Author contributions: Concept -A.K.; Design - A.K, M.M.H.; Supervision- A.K, M.M.H.; Resource - A.K.; Materials - A.K.; G.K.; Data Collection and/or Processing - A.K, M.M.H.; N.K.; Analysis and/or Interpretation - A.K., G.K.; Literature Search -A.K.; G.K.; Writing -A.K.; G.K.; N.K.; Critical Reviews - A.K, M.M.H.; G.K.; N.K.

Conflict of interest statement: The authors declared no conflict of interest.

\section{REFERENCES}

[1] Heywood VH. Flowering Plants of the World. Oxford University Press, Oxford, 1979.

[2] Stevens PF. Erica L. In: Davis PH (Ed). Flora of Turkey and the East Aegean Islands, Vol. 6, Edinburgh University Press, Edinburgh, 1978, pp. 95-97.

[3] Nelson EC. The original material of two Turkish species of Erica (Ericaceae) described and named by Richard Anthony Salisbury (1761-1829). Turk J Bot. 2007; 31(5): 463-466.

[4] Baytop T. Türkiye' de Bitkilerle Tedavi, Geçmişte ve Bugün (second edition). Nobel Tıp Kitabevleri, İstanbul, 1999.

[5] Ekim T, Koyuncu M, Vural M, Duman H, Aytaç Z, Adıgüzel N. Türkiye Bitkileri Kırmızı Kitabı (Eğrelti ve Tohumlu Bitkiler). Van Yüzüncü Yıl Üniversitesi ve Tabiatı Koruma Derneği, Barışcan Ofset, Ankara, 2000.

[6] Tuzlacı E, Eryaşar Aymaz P. Turkish natural medicinal plants, Part IV: Gönen (Balıkesir). Fitoterapia. 2001; 72(4): 323-343. [CrossRef]

[7] Başer KHC, Honda G, Miki W. Herb Drugs and Herbalists in Turkey. Institute for the study of Languages and Cultures of Asia and Africa. Tokyo, 1986.

[8] Antonone R, Simone F, Morrica P, Ramundo O. Traditional phytotherapy in the roccaonfina volcanic group, Campania, Southern Italy. J Ethnopharmacol. 1988; 22(3): 295-306. [CrossRef]

[9] Harnafi H, El Houda Bouanani N, Aziz M, Caid HS, Ghalim N, Armani S. The hypolipidaemic activity of aqueous Erica multiflora flowers extract in triton WR-1339 induced hyperlipidaemic rats: A comparison with fenofibrate. J Ethnopharmacol. 2007; 109(1): 156-160. [CrossRef]

[10] Rios JL, Recio MC, Villar A. Antimicrobial activity of selected plants employed in the Spanish Mediterranean area. J Ethnopharmacol. 1987; 21(2): 139-152. [CrossRef]

[11] Nazemiyeh H, Bahadori F, Delazar A, Ay M, Topçu G, Nahar L, Majinda RRT, Sarker SD. Antioxidant phenolic compounds from the leaves of Erica arborea (Ericaceae). Nat Prod Res. 2008; 22(16): 1385-1392. [CrossRef]

[12] Nazemiyeh H, Bahadori F, Delazar A, Ay M, Topçu G, Kolak U, Nahar L, Auzie AA, Sarker SD. Tricetin 4'-a-Lrhamnopyranoside: a new flavonoid from the aerial parts of Erica arborea. Chem Nat Compd. 2008; 44(2): $174-177$. [CrossRef]

[13] Crowden RK, Jarman JR. Anthocyanins in the genus Erica. Phytochem. 1976; 15(11): 1796-1797. [CrossRef]

[14] Demirkıran Ö, Topçu G, Bahadori F, Ay M, Nazemiyeh H, Choudhary I. Two new phenylpropanoid glycosides from the leaves and flowers of Erica arborea. Helv Chim Acta. 2010; 93(1): 77-83. [CrossRef]

[15] Vieitez E, Ballester A. Phenolic and coumaric components in Erica cinerea. Annales del Instituto Botánico AJ Cavanilles. 1972; 29: 129-142.

[16] Ayuso Gonzalez MJ, Reyes Ruiz M, Toro Sainz MV. Antimicrobial activity of isolated triterpenic compounds from Erica andevalensis Cabezudo-Ribera. An Real Acad Farm. 1991; 57: 419-423.

[17] Reyes Ruiz M, Martin-Cordero C, Ayuso Gonzalez MJ, Toro Sainz MV, Alarcon de la Lastra C. Antiulcer activity in rats by flavonoids of Erica andevalensis Cabezudo-Rivera. Phytother Res. 1996; 10(4): 300-303. [CrossRef] 
[18] Akkol EK, Yeşilada E, Güvenç A. Valuation of anti-inflammatory and antinociceptive activities of Erica species native to Turkey. J Ethnopharmacol. 2008; 116(2): 251-257. [CrossRef]

[19] Ertürk Ö. Antibacterial and antifungal activity of ethanolic extracts from eleven spice plants. Biol, Brat. 2006; 61(3): 275-278. [CrossRef]

[20] Güvenç A, Kendir G, Yıldız S. Antimicrobial activity of Erica L. species (Ericaceae) of Turkey. In: Govil JN, Singh VK, Mishra SK (Eds). Recent Progress in Medicinal Plants. Vol. 20, Phytopharmacology and Therapeutic Values II. Studium Pres LLC, USA, 2008, pp. 173-180.

[21] Kıvçak B, Fafal Erdoğan T, Gönenç T, Pabuçcuoğlu A, Oran E, Kahraman F, Öztürk T. Antioxidant, antimicrobial and cytotoxic activities of Erica bocquetii P. F. Stevens and Erica arborea L. Gümüşhane Univ J Health Sci. 2013; 2(1): $52-65$.

[22] Turgay O, Esen Y. Antioxidant, total phenolic and antimicrobial characteristics of some species. Bulg J Agric Sci. 2015; 21(3): 498-503.

[23] Beghalia M, Ghale S, Allali H, Belouatek A, Marouf A. Inhibition of calcium oxalate monohydrate crystal growth using Algerian medicinal plants. J Med Plants Res. 2008; 2(3): 66-70.

[24] Martin-Cordero C, Reyes M, Ayuso MJ, Toro MV. Cytotoxic triterpenoids from Erica andevalensis. Z Naturforsch C. 2001; 56(1-2): 45-48. [CrossRef]

[25] Ay M, Bahadori F, Öztürk M, Kolak U, Topçu G. Antioxidant activity of Erica arborea. Fitoterapia. 2007; 78(7-8): 571-573. [CrossRef]

[26] Luis A, Domingues F, Gil C, Duarte AP. Antioxidant activity of extracts of Portuguese shrubs: Pterospartum tridentatum, Cytisus scoparius and Erica spp. J Med Plants Res. 2009; 3(11): 886-893.

[27] Pavlovic RD, Lakusic B, Doslov-Kokorus Z, Kovacevic N. Arbutin content and antioxidant activity of some Ericaceae species. Pharmazie. 2009; 64(10): 656-659. [CrossRef]

[28] Nunes R, Anastácio A, Carvalho IS. Antioxidant and free radical scavenging activities of different plant parts from two Erica species. J Food Quality. 2012; 35(5): 307-314. [CrossRef]

[29] Çavdar C, Sifil A, Çamsarı T. Reaktif oksijen partikülleri ve antioksidan savunma. Türk Nefroloji Diyaliz ve Transplantasyon Dergisi. 1997; 3-4: 92-95.

[30] Çoruh N, Sağdıcoğlu Celep AG, Özgökçe F. Antioxidant properties of Prangos ferulacea L., Chaerophyllum macropodum Boiss. and Heracleum persicum Desf. from Apiaceae family used as food in Eastern Anatolia and their inhibitory effects on glutathione-S-transferase. Food Chem. 2007; 100(3): 1237-1242. [CrossRef]

[31] Güvenç A, Houghton PJ, Duman H, Coşkun M, Şahin P. Antioxidant activity studies on selected Sideritis species native to Turkey. Pharm Biol. 2005; 43(2): 173-177. [CrossRef]

[32] Han H, Baik BK. Antioxidant activity and phenolic content of lentils (Lens culinaris), Chickpeas (Cicer arietinum L.), peas (Pisum sativum L.) and soybeans (Glycine max), and their quantitative changes during processing. Int J Food Sci Technol. 2008; 43(11): 1971-1978. [CrossRef]

[33] Orhan I, Özçelik B, Şener B. Evaluation of antibacterial, antifungal, antiviral, and antioxidant potentials of some edible oils and their fatty acid profiles. Turk J Biol. 2011; 35(2): 251-258. [CrossRef]

[34] Alam MN, Bristi NJ, Rafiquzzaman M. Review on in vivo and in vitro methods evaluation of antioxidant activity. Saudi Pharm J. 2013; 21(2): 143-152. [CrossRef]

[35] Conforti F, Statti GA, Tundis R, Menichini F, Houghton PJ. Antioxidant activity of methanolic extract of Hypericum triquetrifolium Turra aerial part. Fitoterapia. 2002; 73(6): 479-483. [CrossRef]

[36] Wagner H, Bladt S. Plant Drug Analysis: A Thin Layer Chromatography Atlas (2nd ed.). Springer-Verlag, Berlin Heidelberg, 1996.

[37] Parr AJ, Bolwell GP. Phenols in the plant and in man. The potential for possible nutritional enhancement of the diet by modifying the phenols content or profile. J Sci Food Agric. 2000; 80(7): 985-1012. [CrossRef]

[38] Singleton VL, Rossi JA. Calorimetry of total phenolics with phosphomolybdic-phosphotungstic acid reagents. Am J Enol Viticult. 1965; 16(3): 144-158.

[39] Brand-Williams W, Cuvelier ME, Berset C. Use of a free radical method to evaluate antioxidant activity. Lebensm Wiss Technol. 1995; 28(1): 25-30. [CrossRef] 